\title{
Restricted, Distorted but Alive: The Memory of the "Lost Generation" of Chinese Educated Youth
}

\author{
Michel Bonnin *
}

\begin{abstract}
During the 1980s, the immediate memory of the Maoist rustication movement expressed itself almost exclusively through the vector of literature, but since 1990, for reasons worth reflecting upon, a wide range of memorial activities have developed, involving a large number of the former educated youth (zhiqing). In the 2000s, this field benefited from the generalization of the internet and is still very much alive today. At each stage, this mainly popular or unofficial (minjian) memory had to negotiate a breathing space with a party-state still intent on controlling history and collective memory, especially concerning any topic directly linked with the Cultural Revolution. Thus, if memories of an important event are always varied because of the different personal experiences of the past and different individual situations and aspirations in the present, the spectrum of the zhiqing memories has also been complicated by political considerations. This paper does not try to present an exhaustive picture of this large memorial field; instead, through different examples, it attempts to reflect upon the meaning of the strong memorial aspirations of the zhiqing. It argues that only a genuine respect for history (as shown in the remarkable endeavours of some former zhiqing) will help this generation to transcend the conflict of memories to find meaning in its own fate.
\end{abstract}

Keywords: zhiqing; Cultural Revolution; collective memory; China; rustication movement

The generation of the Cultural Revolution (urban people who came of age at the time of the Cultural Revolution ${ }^{1}$ ) are in themselves a living legacy of that period. Their collective memory of the period directly influences their conceptions and values, and has an indirect influence on their children. They have been particularly active in all kinds of memorial activities and, given the Chinese Communist Party (CCP) regime's persistent control over historical narrative in

* Ecole des hautes études en sciences sociales (EHESS), Paris. Email: bonnin@ehess.fr.

1 For a more detailed definition of this generation, see Bonnin 2006. 
general, and over that of its own history in particular, these memorial activities unavoidably have a political impact. To understand the breadth of this legacy and its impact, one must rely not only on officially published materials but also on interviews, personal communications and unofficial publications. My 40-year study of the rustication movement incorporates the full range of these sources. ${ }^{2}$ Furthermore, the publication of the Chinese versions of my book in 2009 and 2010 has greatly increased my ability to collect additional material from zhiqing across the country. ${ }^{3}$

\section{The Red Guard Movement and the Rusticated Youth Movement}

If we accept (reluctantly) the official designation of the "ten years of the Cultural Revolution" (1966-1976), ${ }^{4}$ we see that two events marked the members of this generation deeply: the Red Guard movement (1966-1968) and the rustication movement (1968-1980) ${ }^{5}$. The rustication movement (shangshan xiaxiang yundong 上山下乡运动) of 1968 marked the end of the revolutionary period of the Cultural Revolution by bringing the Red Guard movement to a definitive end, and also extended the Cultural Revolution by putting into practice some of the ideas promoted during the movement. The rustication movement, one of the "newborn things of the Cultural Revolution" (wenhua dageming de xinsheng shiwu 文化大革命的新生事物), took different forms during the 1970s, but continued even after the official end of the "ten years" of Cultural Revolution (1977 was the year when the largest number of zhiqing was present in the countryside), coming to a halt only in $1980 .^{6}$

I contend that this movement, which disrupted the lives of about 18 million urban youth as well as those of their parents and siblings (including the 1.3 million who went to the countryside before the Cultural Revolution), ${ }^{7}$ is a key historical event of the time and central to our understanding of Mao and Maoism. One of its legacies for the participants is a strong sense of belonging to a specific generation, which in turn has triggered a desire to share memories through

2 I have been interviewing zhiqing (both formally and informally) since the mid-1970s when I met a group who had swam across to Hong Kong illegally. In 1978, I published under a penname, together with this group of zhiqing and two other French students of China, a book composed of collective interviews (Michel and Huang 1978). I then completed a PhD thesis on this topic, which was later published as a monograph (Bonnin 2004). My research on the zhiqing and the rustication movement thus spans 40 years, and has involved several hundred informants. I have interviewed dozens of former zhiqing, visited zhiqing associations and held collective and individual discussions with their members in Beijing, Shanghai, Hangzhou, Chongqing, Chengdu and Guangzhou.

3 Pan 2009; 2010. Since 2009, a pirate edition of the Hong Kong version has been circulating widely on the mainland.

4 On the topic of the historical periodization of the Cultural Revolution, see Bonnin 2013, XXI-XXII. A broader debate on this question would certainly bring to the fore the extreme complexity of this multifaceted historical event.

5 I use the term "rustication movement" to express the idea of going to live in the countryside. This movement is sometimes called the "up to the mountains, down to the villages movement" following its use in Thomas Bernstein's seminal book (Bernstein 1977).

6 Bonnin 2013, 176-77.

7 Ibid., 62. 
common activities and has led to the development of mutual assistance networks. In The Lost Generation, I offered a tentative historical assessment of the rustication movement in the socio-economic, political and ideological realms. ${ }^{8} \mathrm{~A}$ comprehensive assessment of the historical legacy of the Cultural Revolution as a whole would be a more complicated albeit extremely important task.

My objective in the present paper is more modest. It is to analyse the collective memory of the movement's participants which is comprised of very different and often conflicting individual memories. I also aim to show that the evolution of this memory is itself linked to the historical events and circumstances that continue to unfold right to the present day. I argue that the 4 June 1989 massacre was a determinant of the outburst of zhiqing memorial activities at the start of the 1990s, and I try to explain why. I also demonstrate that this memory is strongly linked to politics, not only because of the regime's will to control the memory of its own past and the enduring suspicion with which it regards social activities, but also because some of the memorial activities and social events organized by zhiqing have led to petitioning, demands for compensation, and the development of mutual assistance networks outside party-state control. Finally, I argue that only a respect for historical truth can overcome the conflict of memories and help those concerned give meaning to their own experience.

This paper builds upon earlier work on the zhiqing by Yang Guobin and by myself (see note 17 below) by incorporating new information and new insights concerning the sudden outburst of memorial activities and nostalgia of the zhiqing in the early 1990s, the social and political meaning of some of the activities of the zhiqing (mutual help but also petitioning), as well as the importance of minjian 民间 (popular, unofficial) history in today's China.

The term zhishi qingnian 知识青年, abbreviated to zhiqing 知青 (educated youth), is not as well-known as the term "Red Guard" (hongweibing 红卫兵) outside of China. ${ }^{9}$ However, I argue that for this generation, their experience as zhiqing has had a deeper and more long-lasting influence than their experience as Red Guards. Not only did their stint as zhiqing last longer (about six years on average, but sometimes ten years or more), but their sojourn in the countryside was also a period of reflection and of a more or less common unified fate. This shared experience gave them a strong sense of a common identity, in contrast to the preceding Red Guard movement, which was chaotic, exceptional and full of infighting and which left little time for rational reflection and little opportunity for the development of common feelings. From the point of view of

8 Ibid., 401-440.

9 The term "zhiqing" (literally meaning "knowledgeable young person") has had different translations in English. "Educated youth" is the closest to the literal meaning and was officially used at the time by the Beijing Foreign Languages Press. I would use it in a paper aimed at a general readership. "Rusticated youth" could be used, too, but is not very common. "Sent-down youth" is less precise, since people sent down (in Chinese: xiafang) are not always sent to the countryside (xiaxiang): it can also refer to being sent to lower echelons of the administrative system. Since this paper is destined for a scholarly journal on Chinese affairs and since the special flavour of jargon is never fully passed on in translation, I shall use the Chinese term "zhiqing." 
collective memory, even if Red Guards would acknowledge the importance of this experience for them, they would not have a feeling of belonging to the same generation through this experience, since they were at the time deeply divided. The two main factions (the conservative baohuangpai 保皇派 and the rebellious zaofanpai 造反派) were themselves divided, sometimes very fiercely, and there was a third group (the unconcerned xiaoyaopai 逍遥派). ${ }^{10}$ On the contrary, even if the zhiqing had different fates according to many factors, such as their socio-political origin, at the time they felt they all were nanyou 难友 (fellow sufferers) and showed strong solidarity.

Another important difference regarding the collective memory of these two experiences is that many former Red Guards recall their time as a painful period, either because they were victims or perpetrators (or both alternately), or were at the very least the passive accomplices in acts of violence, which either they regret or do not wish to remember. The zhiqing had much less opportunity to do evil things (although some of them did, especially if they arrived in the countryside between 1968 and 1970, when the situation in many rural regions was still violent $\left.{ }^{11}\right)$. This is why they prefer to remember the period of their rustication. Many former zhiqing still like to present themselves as "zhiqing," even now they are sixty-something and therefore not young any more. By contrast, very few present themselves today as "Red Guards," even if they acknowledge that they once were Red Guards. As we shall see, there are very different memories of the rustication movement. But, both the proponents of a rosy memory of rustication and its fiercest critics agree that the memory of their experience must be kept alive and, if possible, transmitted to future generations. ${ }^{12}$ There is no such consensus concerning the Red Guard movement.

Of course, another element must be taken into account when comparing the memory of the two movements: the attitude of the authorities concerning the history of that period. The Red Guard movement is officially considered to be a totally negative phenomenon, even to the extent that it is almost impossible to discuss it publicly. This can explain why there are very few books published on the Red Guard experience inside mainland China (and why they have generally been banned soon after publication). ${ }^{13}$ This also explains, at least in part, why the

10 Most works on the Red Guards present the different factions. For a discussion on the diversity of "rebels," see Xu, Youyu 1999a.

11 A description of a commune brigade Party secretary being beaten up by a zhiqing is given in Fan et al. 2013.

12 In the introduction of the rather "critical" collection of memories, Deng Peng writes: "The study of the intellectual journey of the pre-CR zhiqing will help liquidate the poisonous legacy of the Maoist revolution while stories of their struggle to survive and realize their dreams against great odds may well inspire future generations in China." (Deng 2015, 14). However, in a more "nostalgic" collection, the editors assert: "Each person has only one life to live. We have written faithfully about our youthful experience. We offer this writing to the present time, to the young people of the present, hoping that thanks to that comparison between us and the youth of today, we shall all treasure life even more!" (Kong 1998, 4).

13 Since the 1980 s, only a few researchers have been permitted to publish books on the history of the Cultural Revolution, including the Red Guard movement (Bonnin 2007, 54). Outside this official or semi-official realm, some former Red Guards have been able to publish inside the PRC. The most prominent author is $\mathrm{Xu}$ Youyu, a researcher in philosophy at the Chinese Academy of Social Sciences (Xu, 
small wave of remorse expressed by former Red Guards, which appeared in 2013-2014, was quickly stamped out by the authorities. ${ }^{14}$ However, even this fact does not explain why this generation identifies itself more as zhiqing than as Red Guards.

Compared to the Red Guard movement, the rustication movement is less politically "sensitive," but it would be incorrect to assume that the memory of the rustication experience was not and is not restricted by the authorities. ${ }^{15}$ What is particularly striking is that, in spite of the restrictions, the zhiqing are probably the most active group in the realm of collective memory in Chinese society today.

\section{The Memory of a Generation, and its Evolution over More than 30 Years}

I call this generation a "lost generation" because they lost their youthful illusions and the pure idealism on which they were raised as children. They also lost the opportunity to study at the age of study, and this has had a lasting impact for most of them. ${ }^{16}$ Through literature in the 1980s and then through a host of memorial activities, they have been in search of lost time, not in the sense of a Proustian individual search but rather a collective search (similar in this sense to veterans' memory after a war). It is not easy to give a complete picture of the memorial activities of such a large group during a period of about 35 years since the end of the movement. The past is always remembered in the present and then necessarily tainted by present motivations. Some of these motivations concerning the nostalgia and memorial activities of the zhiqing have already been noted: asserting a specific identity and resisting certain trends in society that tend to marginalize them, fighting against the official oblivion of the Cultural Revolution. ${ }^{17}$ Thus, the spectrum of memories, which is always varied because of the different personal experiences of the past and different individual situations and aspirations in the present, has also been complicated by political considerations.

footnote continued

Youyu 1998; 1999b). It has recently been more difficult to publish on this topic, but many studies and testimonies have been circulating via electronic magazines such as Jiyi (Remembrance) and Zuotian (Yesterday) among a selected list of specialists and interested scholars. Their archives are now fully available on the site of the PRC History Group: prchistory.org.

14 "Cultural Revolution: time to say sorry," The Economist, 29 August 2013; Xiao 2014; Pedroletti 2014; as well as the special issue published in Jiyi 106, 15 January 2014.

15 Restrictions can fluctuate according to the regime's sense of insecurity and calculations of political risk. For example, the main two-volume work on the history of the movement published by Chinese scholars was subject to alterations. Following its publication in 1998 for the 30th anniversary of the movement, the publisher was not permitted to reprint it until the 40th anniversary (conversation with the authors). See Ding 1998; Liu 1998. My own book was initially accepted for publication by a Chongqing publisher who was not allowed to publish it, whereas my Beijing publisher was given the green light one year later.

16 Bonnin 2013, 433-34.

17 Yang, Guobin 2003; Bonnin 2007; 2011. 
As memory is itself subject to historical study, it is interesting to see how these activities have developed. From the end of the 1970s to the end of the 1980s, the memory of this generation expressed itself almost exclusively through literature. As restrictions imposed in this domain are very relaxed, a kind of neo-realist literature surfaced which fulfilled a cathartic role after the terror and sufferings of the Cultural Revolution. Zhiqing writers, some of whom wrote secretly for years during their rustication without any hope of being published, began to create a zhiqing literature, which formed a large part of the extremely popular literary magazines of the time. Immediately, they spoke for their entire generation, almost never from an individual point of view, but referred to "us" and "our generation." 18 True, as Yang Guobin remarks, at first they exposed the wounds of their generation, but if you look closely at this literature during the whole decade, you can find also many expressions of nostalgia, of pride at belonging to this generation, of praise for its "heroism." 19 In any case, writers seem to have retained the monopoly of preserving this collective memory. They seem to be invested with that task by the rest of the zhiqing. ${ }^{20}$ In fact, the first works of oral history concerning that generation were also produced by writers, and not by historians or journalists. ${ }^{21}$

I have asked many zhiqing why there were no other collective expressions of memory during the 1980s. ${ }^{22}$ Their answer is generally that they were "too busy at the time." In fact, the lives of the zhiqing were seriously disrupted by their rustication. This is why they are sometimes described as a "delayed generation" (danwule de yidai 耽误了的一代). ${ }^{23}$ After their return to the cities at the end of the 1970s, they had to make up for lost time and find work, study, marry and have children, all fundamental activities that would normally have happened at an earlier point in their lives had they not been rusticated. Only at the end of the 1980s did they feel more established and were they finally able to care about matters such as reflecting upon their rural experience.

What is striking is the change that occurred in 1990-1991, with the staging of some big zhiqing exhibitions and the writing and first publication of historical/ memorial books about the rustication movement. Why precisely at that time?

Yang Guobin argues that this surge in zhiqing nostalgia was the result of the very specific experience they had had during their adolescence and of an identity crisis triggered by the rapid social changes caused by the economic upheavals. ${ }^{24}$ This is certainly true over the long term. But the most destabilizing social changes appeared only later, in the years following Deng's Southern Tour at the

18 See, e.g., Bonnin 2013, 432, Fn. 22.

19 Ibid., 439-440. On this literature, see Yang, Jian 2002; Wang, Lijian 2008; Qin 2006.

20 Bonnin 1986.

21 Feng 1991; Zhang, Xinxin, and Ye 1986.

22 In fact, there were some private activities, like trips organized by small groups of former zhiqing to the village or farm where they had been sent, but nothing public or large scale.

23 Bonnin 2013, 434.

24 Yang, Guobin 2003, especially 273-76. 
beginning of 1992. In fact, after the events of 4 June 1989, reforms had slowed down and there was even a return to more "socialist" policies. ${ }^{25}$

My own hypothesis is that this surge in zhiqing memory in 1990-1991 is linked to "4 June" in two different ways: for the zhiqing themselves and for urban society as a whole, 4 June in a way blocked the future. The 1980s had been a time of hope, of openness to the outside world and to Western ideas, ${ }^{26}$ and of economic and social reforms that were also supposed to bring about political and ideological reforms. ${ }^{27}$ As was shown by the debates concerning the film River Elegy (Heshang 河歾), there was a strong aspiration to develop a new "blue culture" in China (blue being the colour of the ocean, a symbol of openness to the outside) to combat the burden of the traditional "yellow culture" (yellow being the symbol of the yellow earth around the Yellow River, where China had originated). ${ }^{28}$ The massacre perpetrated during the night of 3-4 June 1989 in Beijing killed not only people but also this optimism and this openness, especially as the authorities did all they could to reject everything new and Western in the ideological realm and to encourage Chinese people to go back to their own cultural and historical roots. ${ }^{29}$ This is the period when traditional practices like martial arts, qigong and even the belief in all kinds of fantastic "supernatural powers" (teyi gongneng 特异功能) flourished suddenly, especially among very official institutions such as the police and the army. ${ }^{30}$ Under these circumstances, the zhiqing nostalgia, which had always been latent, became more pressing and, at the same time, the authorities were more willing to allow the zhiqing to organize memorial activities (and in fact they encouraged these activities so long as they could control their content). Even if the 1960s and 1970s were a sensitive time, this sensitivity was much less dangerous than the recent past of the spring of 1989. In a way, the tolerance shown by the authorities could be explained as the use of one memory to obfuscate another one. It could also be described as letting some steam out in a tense situation. The first zhiqing exhibition, which opened in November 1990 in the Beijing History Museum (bordering Tiananmen Square, where the 1989 events had taken place), had a strong official "flavour." The exhibitions that followed, in Hainan, Chengdu and Nanjing in 1991 and 1993, were also staged

25 Barry Naughton, discussing economic policy, writes that, "The 1990s policy regime emerged with unmistakable clarity only a few years after the Tiananmen crisis, in 1993-1994." He points to "a surprisingly radical retrenchment of reforms" just after Tiananmen. See Naughton 2011, mainly 154-166. See also Lam 1995, mainly 51-75.

26 Wang, Runsheng 1992.

27 In 1986, Deng Xiaoping himself promoted the idea of political reform before changing his mind. The two successive Party general secretaries chosen by him, Hu Yaobang and Zhao Ziyang, were both in favour of some kind of reform. See, e.g., Ruan 1994.

28 On the meaning of the River Elegy (Heshang), see Chen, Fong-ching, and Jin 1997.

29 In a way, this turn towards the past is still strong today. Even though Deng Xiaoping succeeded in the economic realm to point China again in a forward direction, in the political and ideological realms, the horizon is still blocked by strong prohibitions and by the very historical existence of 4 June 1989. While the Party is unwilling to face this historical black point, it is difficult to imagine how Chinese society will be able to open new political and intellectual horizons.

30 This was the breeding ground for the development of the Falun Gong, which later posed a problem for the authorities. See Palmer 2007 and Ownby 2010. 
under the patronage of the municipal authorities and blessed by the calligraphies of top local leaders. ${ }^{31}$

The sudden emergence of unofficial historical books on the rustication movement after 1990 is also intriguing. Before 1989, apart from some "internal" studies not available to the public, the only historical account of the movement had appeared in 1987 as a small chapter in a book written by Party researchers that gave an official presentation of the "ten years of the Cultural Revolution." 32 However, two historical books on the movement, written by former zhiqing with no official backgrounds, were published in 1992 and 1993 (one of them having been ready since the end of 1990). Others followed during the 1990s. These books, of course, could not have been published without official approval. ${ }^{33}$

It is also interesting to note that this is precisely when Deng Xiaoping 邓小平 himself began to acknowledge in front of his colleagues the fact that the evaluation of Mao Zedong 毛泽东, made in 1981 under his leadership, was not satisfactory from a historical point of view. In the summer of 1991 and again in January 1993, he said that it had only been a political necessity and would be revised by the next generation in "ten or eight years." 34 Deng, who had taken the ultimate decision for the 4 June crackdown, ${ }^{35}$ a decision that demonstrated his paramount power but would probably remain as a stain on his own biography, was ready soon after that to contemplate the revision of Mao's official image, which seemed cast forever by the 1981 Resolution. Although a complete study on this topic has yet to be made, it seems that the trauma of 4 June 1989 has brought China to a new "regime of historicity," which means a new relationship between a society and "time": in this case, a backward-looking tendency to reflect on the more distant past so as to forget the painful present or immediate past, in a situation when previous hopes for the future have been disappointed. ${ }^{36}$ The nostalgic mood of Chinese society (which was in total contrast to the idealistic and often impatient expectations concerning the future prevalent in the 1980s) appeared very soon at the beginning of the 1990s. As such, in 1994 a new publishing company, Huaxia publishing house 华夏出版社 (with links to the political department of the $\operatorname{army}^{37}$ ) decided to publish a series of books dedicated to

31 Interviews conducted in Beijing in 1991 with a famous zhiqing writer who was familiar with the organizers but refused to take part in it because it was too "official," and in Chengdu in 2008 with a group of organizers of the 1991 exhibition. One of them, Qu Bo, gave me some original documents concerning the exhibition. See also Yang, Guobin 2003. On the Beijing exhibition, see Hunxi hei tudi bianweihui 1991.

32 Bonnin 2013, xxxiii.

33 An article that I published in 1989 in an audacious but short-lived magazine in liberal Hainan province appears to have had some influence on the first Chinese unofficial historians of the movement, along with the later publication, in 1993, of a Chinese version of Thomas Bernstein's (1977) book. The publication of Bernstein's book also shows a new tolerance concerning this topic. See Bonnin 2013, xxxiiixxxv.

34 Xin 2007, vi; Guo 2010.

35 Zhang, Liang, Nathan and Link 2002.

36 See Hartog 2003.

37 Information from a famous zhiqing writer who published with this company and who was asked to act also as a literary advisor. 
nostalgia under the title Collection of Nostalgia Literature. An excerpt from the general preface to the collection and one from the postscript of the fifth volume illustrates this change in the "regime of historicity":

The sad present has not been able to give us new ideas or new forms which we can acclaim and recall with dignity. So we have no other choice but to look behind us and return to the past.

One of my friends said to me: "Tomorrow is born of yesterday, not of today. I can only concoct my dreams of the future from the traces of the past." These words are an accurate reflection of the mentality of certain urban intellectuals today. Unable to imagine what tomorrow will hold, they try to avoid falling in a state of open anxiety by intoxicating themselves with heady draughts from the past. ${ }^{38}$

Also at that time, another form of memorial activity suddenly emerged in the form of zhiqing restaurants, which opened in many large cities and especially in Beijing. In these restaurants, diners could eat the cuisine of the different regions where the local zhiqing had been sent, in surroundings and décor reminiscent of the life of the zhiqing at that time. ${ }^{39}$ They could thus spiritually feed themselves with symbols of their own past. There was, of course, a commercial motive behind these restaurants, but they had a social and cultural function. They became places where former zhiqing could get together again, and in one restaurant, diners could pin their name card to a big board, in the hope that a former pal from this period would then be able to get in touch. ${ }^{40}$ Sometimes, these restaurants were used as gathering places for groups of former zhiqing who not only wanted to eat but also wanted to talk among themselves. The authorities were suspicious of these gatherings and in some cases banned them or punished the restaurant owners by closing their enterprise for a period of time. ${ }^{41}$

During the 1990s, the groups which had organized exhibitions, along with many other groups of zhiqing, began publishing collections of remembrances. This broke the monopoly on memory formerly enjoyed by professional writers. Ordinary zhiqing were able to retell their stories of their rural experience and share their present feelings about it. Of course, these publications all had to pass through censorship, but with time their number increased. In 1998, for the 30th anniversary of the launch of the movement, the authorities permitted the publication of many of these books. And, during the 2000s, the rapid development of the internet gave more people the opportunity to take part in memorial activities through remembrances and discussions posted on zhiqing websites. These websites were created by small groups of zhiqing friends and were instrumental to creating more important associations, giving a new visibility to their activities. Hard print magazines were also produced in the major cities. ${ }^{42}$

Some of these activities were certainly stimulated by the mercantile atmosphere of the 1990s, which has prevailed under new forms until now. There is an obvious economic incentive behind the restaurants, the selling of albums of old zhiqing

38 Author's translation. More examples and precise references can be found in Bonnin 1996, 38.

39 Ibid.; Hubbert 2005.

40 Hubbert 2005, 40.

41 Ibid., 38.

42 Yang, Guobin 2003. 
songs and also the organized trips to the original places of rustication, with the association acting as a travel agency. But, from my interviews with many of the people in charge of these associations, it appears that the commercial motivation for most of these activities is at best secondary. In fact, the costs often outweigh the returns. These activities rely mostly on volunteer work, and when some businessmen play an important role in the association, it is generally because they are the only ones who can afford to provide funding without a return. Their motivation is partly the traditional one for merchants and businessmen in traditional society inside China and in the diaspora, which is to gain prestige by promoting socially useful activities and doing charitable works. It is very often difficult to doubt the sincerity of their desire to do something meaningful for the memory of the rustication movement. ${ }^{43}$ It must be remembered that these activities can not only be costly but can also be a source of contention with the authorities. Moreover, the numerous conflicts that arise between different groups or individuals inside the association can easily become a headache for those in charge. From my discussions with some of the group leaders and my observations of the ups and downs of the life of these associations, it seems that only a strong feeling of belonging to a special community (the zhiqing, and especially the zhiqing of a certain city) and the personal satisfaction they get from doing useful things for this community can fully explain the time and energy these people commit to these projects.

Since the end of the 2000s, museums, big and small, along with permanent exhibitions, have been established across the whole of China to keep the memory of the movement alive. They are the result of individual initiatives by former zhiqing, sometimes with the help of official institutions. Some, like the Heihe Zhiqing Museum 黑河知青博物馆 in Heilongjiang, initiated by former Shanghai zhiqing under the leadership of the Political Consultative Conference of Heilongjiang province, give a very positive assessment of the rustication experience, while others, such as the Jianchuan Museum 建川博物馆 in Dayi county 大邑县 near Chengdu and the Shanghai Zhiqing Museum in Haiwan Park 海湾公园 (in Shanghai's Fengxian district 奉贤区), give a more balanced presentation, including, for example, photos and documents concerning the zhiqing campaign to return home at the end of the $1970 \mathrm{~s} .{ }^{44}$

\section{Different Memories Competing}

Different feelings are expressed in all of these memorial activities but, since the 1990 s, the most pervasive is certainly nostalgia. I call this nostalgia "paradoxical nostalgia," or "a nostalgia for the bad old days," since at the time of the movement almost all of the rusticated youths had only one goal in mind: to leave the

\footnotetext{
43 I do not want to give names here, but I am thinking specifically of two people, one in Shanghai, one in Chengdu.

44 Personal documentation.
} 
countryside. Virtually no one stayed there when they had the opportunity to return to the cities.

This paradoxical nostalgia can be explained by the fact that their youth has passed and because they came through an exceptional experience which marked them deeply. They can express a kind of pride and satisfaction because nobody will go through the same experience after them. But, even the more nostalgic and proud have learned something. They do not really want to go back to Mao's time. They do not respond when other zhiqing remind them that they left the countryside and that they would not like their children to be rusticated like them.

So, the zhiqing nostalgia of the 1990s had a post-modern flavour. It was more the result of unease about the present and anxiety about the future than a real desire to go back to the past. It was a time of derision and cynicism, as expressed in the very popular novels of Wang Shuo 王朔. In one nostalgic zhiqing restaurant, I remarked that someone had added small moustaches to the portraits of Mao and Lin Biao 林彪 on the old newspapers covering the walls and ceiling. Nobody seemed to care. ${ }^{45}$ The 1990 s was also a period when Mao and the Cultural Revolution were widely packaged as merchandise. Indeed, it could be said that the more that Mao and the Cultural Revolution were marketed, the more the ideals they incarnated sank into the past. ${ }^{46}$

It is worth noting that those zhiqing who gained a degree of success after their return to their cities tend to have a more positive memory of their experience and thus are more nostalgic. There are remarkable exceptions to this tendency among the scholars, writers and artists of that generation, but generally speaking this seems to be true, especially among officials and businessmen. In both categories, rustication is often used as a form of political capital, a way of demonstrating that their success was not obtained easily but only through hardship and perseverance at the grassroots level, that they had been "tempered" by the rustication movement as Mao had wished. ${ }^{47} \mathrm{Xi}$ Jinping 习近平 probably provides the best example of this use of the zhiqing experience as political capital, as shown by his high-profile Chinese New Year visit in 2015 to his rustication place in the North Shaanxi region. ${ }^{48}$ In 2002, Xi wrote an account of his sojourn in the countryside called, "I am a son of the yellow earth." In a move reminiscent of Mao's days, this text was transformed into a song with the same title in $2014 .{ }^{49}$

45 Bonnin 1996, 39.

46 Ibid. On the Mao nostalgia of that time, see Barmé 1996; 2000, 316-344.

47 Of course, they forget that Mao had certainly not intended that this movement should produce such people as capitalist entrepreneurs and Party leaders with rich families.

48 See, e.g., "Xi Jinping chonghui Yan'an chadui cunzhuang, yong Shaanbei fangyan jieshao Peng Liyuan" (Xi Jinping goes back to the village where he was sent, uses the north Shaanxi dialect to introduce Peng Liyuan), Xinhua, 14 February 2015, http://view.inews.qq.com/w/WXN201502140077890A1? refer=nwx. Accessed 28 June 2016. It was not the first time that Xi Jinping went publicly back to this place. For the text of Xi's account of his sojourn in the countryside, see Xi 2002.

49 Baidu baike. 2014. "Wo shi huang tudi de erzi" (I am a son of the yellow earth), http://baike.baidu.com/ link?url=QKDBX0fPN1WOXaJHcARRYovQ8esrdWUYzS0wsJEFhYG5k5lomTbNL0opOMkuya ECduLHL7qVFmGwDRrTbnTg2q. Accessed 27 June 2016. 


\section{A Wide Spectrum of Memories between Nostalgia and Rejection, Denunciation and Approval}

So, we can differentiate between two types of memory, one nostalgic and one critical, but it is not a clear black-and-white picture. Feelings about the zhiqing experience are often mixed and not as clear-cut as it would appear. For example, the Chengdu zhiqing who organized one of the first exhibitions in June 1991 used a title which became the motto for all nostalgic zhiqing: qingchun wuhui 青春无悔 (often translated as “we have no regret for our youth”). ${ }^{50}$ During my discussions with some of the organizers in 2008 and 2009, they told me that while the title was in fact chosen by the municipal authorities (who discussed all the details of the exhibition before authorizing it), they had accepted it because it reflected their feelings. They were later surprised by the fierce criticism of some who accused them of lacking a critical distance from a movement that had brought so much trouble and loss to their generation. They objected that, for them, the meaning of qingchun wuhui was in fact qingchun wufa hui 青春无 法悔 (we have no means to regret our youth). They could not regret this youthful experience because it was a fact of the past that they had not chosen in the first place. It was imposed upon them, but as it had become an important part of their lives which had left indelible traces in their hearts and become part of their collective identity, they just had to face it and, most importantly, to keep its memory alive. The possibility of remembering publicly this period of their lives and organizing an exhibition that would bring them together again allowed them to pay tribute to those zhiqing who had lost their lives in Yunnan (part seven of the exhibition). It also revealed to their children an important part of their personal histories, and in their opinion justified the compromises they had had to make in their discussions with the municipality concerning the title and the content of the exhibition. They later published a collection of recorded memories using the same title: Qingchun wuhui. ${ }^{51}$ But, many years later, some of them also collaborated in the publication of another edited volume that demonstrated that their nostalgic feelings and their sense of belonging to the special community of "zhiqing" did not necessarily mean that they lacked a critical distance from their past. ${ }^{52}$ Not only did they show in this book the dark aspects of that time and proudly remember the protests that had culminated in their return to the cities, but they also took action to repair one injustice left from that period. Having heard that a zhiqing from Chongqing, Jiang Shihua 姜世华, was left crippled and thus unable to work as a result of the ill treatment he had received at the Yunnan farm to which he had been sent aged 17, and that he had not received any help following his return to Chongqing, this group of zhiqing used the internet and

50 The subtitle was: "Chengdu zhiqing fu dian zhibian huigu zhan" (Retrospective exhibition of the Chengdu educated youth sent to support the border in Yunnan). A special envelope marking the event was issued by the Stamp Company of Chengdu.

51 "Qingchun Wuhui” bianjizu 1991.

$52 \mathrm{Qu}$ and Luo 2006. 
their "relations" to help Jiang secure a small monthly stipend from the farm, and published the story in their book. ${ }^{53}$

However, "critical memory" is also complex. Painful memories (of physical and moral pain suffered at the time) can easily transform into a critical memory denouncing the system that inflicted those wounds on the zhiqing individually and collectively. Fewer people express such memories because remembering pain is itself painful. This is why many zhiqing simply "do not dare to look back" (bu kan huishou 不堪回首), and even when they are emboldened to do so, they may still be subject to censorship by the authorities. Still, expressions of painful memories do continue in the public domain, especially in literature and cinema. ${ }^{54}$

Even those zhiqing who are more critical of the movement evince traces of nostalgia. This is the result not only of the usual nostalgia of youth but also of their personal feelings towards other zhiqing or peasants, which emerged naturally from many years spent together in the countryside. The specificity of Maoist society, which imposed the same ideology and the same simplistic culture upon everybody, can also explain why people who may have different conceptions of life today still have a strong sense of a common identity that is triggered by old songs, films or texts that were popular during their time in the countryside. Even dissidents of that generation (including people extremely critical of Mao) participate in singing "red" songs glorifying Mao when they wine-and-dine together in the US, if only because they simply cannot recall other songs from their youth. ${ }^{55}$

Thus, sentiment and reason are not always in line with the memories that the zhiqing retain of their experience and the assessment they make of it. A "nostalgic memory" can trigger a totally positive evaluation of the rustication policy but can also coexist with a more balanced evaluation. A "critical memory" can be supported by mainly bad personal remembrances or trigger a refusal to remember the whole period. It can also blend a negative assessment of the movement with personal nostalgic feelings. This variety is still further complicated by the links, inevitable under the Chinese regime, between memory and politics.

\section{Memory and Politics}

We have seen that in the case of the Chengdu zhiqing who organized one of the first exhibitions, politics (in this case, approval from the municipal authorities)

53 Ibid., 471-596.

54 In cinema, the most famous movie expressing the despair felt by female zhiqing, who were faced with sexual harassment and rape by local cadres, was directed in the US by Chinese actress Joan Chen (Xiu Хiu (The Sent-down Girl) 1998). In the realm of literature, which is less strictly controlled than cinema inside China, most of the works by zhiqing authors at the time of the "scar literature" and even later express some aspects of their difficulties and pain. This is the case for both mainstream authors like Ye Xin in Cuotuo suiyue (Ye 1980) and more marginal authors like Xu Naijian in Yangbai de wuran (Xu, Naijian 1981). With the passage of time, the expression of pain has been transformed into irony and black humour, as in Wang Xiaobo's Huangjin shidai (Wang, Xiaobo 1997).

55 Meeting with Hu Ping, 31 March 2014. 
influenced their memorial activity. From the discussions I had with zhiqing in other cities, it appears that many agree that it is worth compromising with the authorities in order to hold large-scale memorial activities. But, there are often disputes, resulting in splits or even boycotts because of differing views on the necessity of such compromises. Quite often, a group of zhiqing brand another group or leader as "traitors" for siding with the authorities and trying to please them, while the more accommodating group in turn regards the hold-outs as "troublemakers" with politically motivated agendas that could lead to the banning of their association and activities..$^{56}$

Such conflicts are the inevitable result of the authorities' determination to control both the form and content of zhiqing memorial activities. This determination has not abated, even decades later. This is particularly true in the case of highprofile zhiqing memorial activities. For example, in December 2013, on the 50th anniversary of their departure, a group of former Shanghai zhiqing, who were dispatched to the Xinjiang Production and Construction Corps, organized an evening party in a large venue which could accommodate up to 3,000 former members of those farms and their families. As they are older than the Cultural Revolution zhiqing, and as many of their original number are now deceased, this commemoration was particularly poignant. But it was very difficult to get municipal approval for the event, since the Xinjiang zhiqing are considered to be particularly restive. They were forced to submit the names of all invitees in advance and to invite a few former "model zhiqing" who continue to spread propaganda for the movement (which generates lifelong political capital and economic benefit for them, as they also manage business ventures linked to memorializing the rustication movement). It goes without saying that those who continue to petition for the improvement of the conditions of the zhiqing were excluded. As a result of such deliberate staging, the DVD of the event carries no mention of the harsh fate and the discrimination that the Xinjiang zhiqing suffered. The texts of the speeches given at the event, as well as the content of all the artistic performances, were pre-screened and a few officials and former "model zhiqing" were also put on the programme. The only spontaneous "free expression" was a brief extemporaneous statement uttered by the main organizer, in which he said that history would judge whether their petitioning movement of 1979-1980 had been justified. As the leader of this failed petitioning movement, he had been jailed for four years and had consequently led a very difficult life after his release. It was probably the least that he could do from a moral point of view, but it was also the most he could have said without risking the pre-emptive closure of the event. ${ }^{57}$

56 Different interviews with former zhiqing from Shanghai, Chongqing and Beijing between 2008 and 2014.

57 Discussion with Ouyang Lian and other participants in the conference, 20 December 2014. The collection of the three DVDs is called Huihuang de shenghui, 1963-2013: Shanghai zhibian zhishi qingnian fu Xinjiang tunken shubian wushi zhounian jinian dahui (A Glorious Meeting, 1963-2013: Memorial Meeting for the 50th Anniversary of the Departure of Shanghai Educated Youth to Help the Border and Reclaim 
Clearly, the official need to control this 2013 event was as pronounced as it had been for the 1991 Chengdu exhibition. But, in both cases, the organizers thought it worthwhile to make the concessions in order to keep the memory alive.

What explains the persistent determination of the authorities to control the memory of the rustication movement down to the present day? The reasons, I think, are twofold. The most important is certainly the desire to maintain a positive image of Mao and the history of the People's Republic of China (PRC) as a source of political legitimacy. Even before Xi Jinping announced that it was not permissible to use the last 30 years of PRC history to critique the 30 years which preceded, ${ }^{58}$ I was often asked: "if you consider us a 'lost generation,' how do you explain China's rapid development and extraordinary successes after the rustication movement? It is precisely because rustication was a good policy that China could develop rapidly during the reform period." However, the contrary explanation also receives wide support: it is precisely because such policies were abandoned and radical changes were adopted that China was able to catch up very quickly and leave behind the sad state in which Mao left his country at the end of his life. ${ }^{59}$ However, it is more difficult to convince the Party leaders who are striving to create a "globally positive" image of the Maoist period and to label all fundamental criticism of it as "historical nihilism." Xi Jinping's denunciation of "nihilism" is clearly linked to the Chinese Communist Party's ability to hold on to power, since the fall of the Soviet Union is attributed in part to a similar "nihilism" during the last days of the USSR. ${ }^{60}$

\section{The Question of Compensation}

Aside from the image of Mao and of the regime in general, the risk of being presented with compensation claims is certainly one reason why the authorities seek to limit the expression of zhiqing memory and why they attempt to channel it in the direction of a globally positive appreciation of that experience.

The authorities are indeed confronted with a militant memory. Some groups of zhiqing remind them of the pains that they suffered and which are not yet over. For these zhiqing, the past is not past and they demand a solution to their present problems. The most important group still making collective claims today is that

\section{footnote continued}

Land in Xinjiang). On Ouyang Lian (and the Xinjiang zhiqing protest movement), see Liu 2004, 445529, and Bonnin 2010.

58 "Xi Jinping: gaige kaifang qianhou de lishi bu neng huxiang fouding" (Xi Jinping: the historical periods before and after the reforms cannot be opposed to each other), Xinhua, 5 January 2013.

59 “Due to Mao's initiatives, China had fallen increasingly behind other nations in its quest for development. Mao left a country that was backward and weak, having fulfilled few of the aspirations of the early 1950s." Walder 2015, 315.

60 Zhonggong zhongyang dangshi yanjiushi. 2013. "Zhongyang dangshi yanjiushi chanshi Xi Jinping liangge bu neng fouding lunshu" (The Central Committee Research Centre on Party History explains Xi Jinping's discourse on the two periods which cannot be negated), Renmin wang, 8 November. 
of the Shanghai zhiqing who were sent to Xinjiang before the Cultural Revolution. Members of this group are making demands for compensation because of the discriminatory treatment they have suffered since the beginning of the 1980s, when they, unlike other zhiqing, were not permitted to return to Shanghai. ${ }^{61}$ This refusal has triggered a whole host of difficulties for them that continue right up until the present day. In 2000, they tried to organize a delegation of 50 zhiqing to go to Beijing to explain their plight to the central authorities. However, before they could depart, they were arrested and three were jailed for a period. Some of them even tried to sue the mayor of Shanghai but, of course, the tribunal did not accept their case. ${ }^{62}$ When Xi Jinping became the Shanghai Party secretary in 2007, they wrote an appeal to him and organized a small demonstration with a banner welcoming "the old zhiqing Xi Jinping" to Shanghai. But it was to no avail: $\mathrm{Xi}$ never replied and left Shanghai after a few months to become a member of the Standing Committee of the Politburo. ${ }^{63}$

Similarly, Ding Huimin 丁惠民, a zhiqing who was the former leader of the Xishuangbanna 西双版纳 protest movement of 1978-1979, tried to organize a delegation of former rusticated youths from Chongqing to go to Beijing in 2009 to demand a solution to the many problems that still plague them; however, he was arrested at the station and sent for re-education through labour. ${ }^{64}$

In addition to these petitions for compensation, the notion has often been expressed that the state owes something to the zhiqing as a victimized group. ${ }^{65}$ This serves to reinforce the determination of the Party to supervise zhiqing memorial activities.

The zhiqing, however, do not rely only on authorities: one function of their memorial activities is to organize mutual assistance for zhiqing in need. Very often, those who have fared better provide funding to those less fortunate than themselves, for example, by purchasing computers or paying the travel expenses of zhiqing who are less well off.

Such assistance can have political overtones when zhiqing are mobilized, for instance in the aforementioned case of Jiang Shihua. Similarly, the writer Lao Gui 老鬼, who was sent to Inner Mongolia, organized funding to erect a monument to the 29 zhiqing who had died fighting a forest fire there, and published a commemorative book of parents' accounts of each of the zhiqing martyrs. ${ }^{66}$ Former zhiqing who have attained a high social status use their influence to urge the authorities to redress injustices and provide comfort to the victims of the rustication movement. This type of zhiqing mobilization in self-protection

61 Bonnin 2004, 192-202; 2010.

62 Different meetings with the "three scholars" (san xiucai) from the group of Xinjiang former zhiqing who continue to make regular claims for compensation, and the personal collection of documents produced by this group.

63 Ibid.

64 Communication with a friend of Ding Huimin and postings on Sina Weibo by his lawyer, Liu Xiaoyuan.

65 For a clearly articulated expression of this idea, see Chen, Yixin 1999.

66 Lao 2009. 
is a salient and positive legacy of their experience in the countryside, even if its overall effects are limited.

\section{History as a Way to Transcend the Conflict of Memories}

Conflicting memories shared among the zhiqing can become polarized, particularly on the internet, and deter those seeking more serious reflection about their fate and that of their generation. Memories of the rustication movement (minjian jiyi 民间记忆) and unofficial histories (minjian lishi 民间历史) were penned during the 1990s by former zhiqing who were motivated by a desire to overturn myths, to salvage the history of this period from oblivion and to restore a true image to the movement. Some of the authors were professional historians working on earlier periods (Liu Xiaomeng 刘小萌 and Ding Yizhuang 定宜庄, both researchers studying the Manchu dynasty at the CASS) or scholars in other fields, such as Xu Youyu 徐友渔 or Shi Weimin 史卫民. Other authors included former leaders or cadres who had worked in the administration of the xiaxiang movement (for example, Gu Hongzhang 顾洪章, Zhao Fan 赵凡, Xu Fa 许法 and Xie Mingan 谢敏干). ${ }^{67}$ Some of these works were published by official publishers, others unofficial: samizdat (ziyinshu 自印书), independent documentaries or electronic magazines sent to a list of selected people. Only in Shanghai has the work of historians of the rustication movement been recognized as a regular academic activity. Some of these historians work closely with minjian associations (for example, Jin Dalu 金大陆 and Jin Guangyao 金光耀). ${ }^{68}$ All of these researchers were either zhiqing themselves or cadres in charge of zhiqing. More recently, a handful of younger scholars have emerged whose work may allow this field of study to outlive the zhiqing generation itself. Not surprisingly, they are all children of zhiqing and are concentrated in Shanghai. Even people who are not trained as scholars have, in their collections of testimonies, gathered and compared different accounts of the same event, and found valuable information in old newspaper accounts. They, too, have thus contributed to the broader effort to preserve the historical truth and to preserve memory enlightened by historical data. ${ }^{69}$

History is indeed a way to transcend the conflict of memories. It can give the former zhiqing a satisfying sense of comprehending their own destiny. To younger generations, it is useful to know something about the history lived by their parents and grandparents. But it remains difficult to overcome the political interests and prejudices of those who are not primarily interested in truth and reflection, particularly when free debate on the Maoist period is still impossible because of

67 For a list of the main works of these authors, see the Bibliography in Bonnin 2004, as well as in Bonnin 2007.

68 Bonnin 2007. The Shanghai researchers are doing a very useful job of compiling reference materials and chronicles for further historical research. See Lin and Jin 2014, as well as Jin, Jin and Shanghaishi zhishi qingnian lishi wenhua yanjiuhui 2014.

69 See, e.g., Qu and Luo 2006. 
official restrictions. Unfortunately, half a century after the launch of the Cultural Revolution, no one can tell when a balanced historical study of this period will be possible in China itself. Still, in spite of the difficulties, the former rusticated youth have shown a remarkable energy in maintaining the memory of their exceptional experience. Some have already made important contributions to a future detailed and rational history of the Maoist era. To attain this goal, they need to liberate their thinking from the propaganda of the time, which was never officially criticized and is frequently revived for political purposes. This task has a deep meaning for China and for the rest of the world. I suggest that, in China and abroad, dedicated historians of the rustication movement and of the Cultural Revolution meditate this appeal made by the French historian Jacques Le Goff: "Memory [...] endeavours to save the past only to serve the present and the future. Let's see to it that collective memory serves the liberation of men and not their enslavement." 70

\section{Acknowledgement}

Research for this article was funded by the ANR under the ANR-RGC collaborative project, "New approaches to the Mao era (1949-1976): everyday history and unofficial memory" (2013-2016).

\section{Biographical note}

Michel Bonnin is professor at the Ecole des Hautes Etudes en Sciences Sociales (EHESS), Paris. During the 1990s, he was the director of the French Research Centre on Contemporary China and of the magazine China Perspectives, both of which he founded in Hong Kong. His 2004 book, Génération perdue. Le mouvement d'envoi des jeunes instruits à la campagne, Chine 1968-1980, which gives a global presentation of the rustication movement of China's educated youth, has two Chinese editions published in Hong Kong and Beijing, and an English edition entitled, The Lost Generation: The Rustication of China's Educated Youth (1968-1980) ("Choice Outstanding Academic Title, 2014"). His main research interests are the social and political questions of the People's Republic of China. He has written mostly on the rustication movement of urban educated youth during the 1960s and the 1970s, on the democratic movement in China, and on popular history and memory, as well as on the question of generations in contemporary China.

摘要: 在 1980 年代, 毛泽东发动的上山下乡运动的记忆基本上只是在文学 中才有所表达。但有一件事值得我们反思: 自 1990 年起, 各种记忆活动开 始出现, 涉及的前知青数目也相当大。在 2000 年代, 记忆活动因互联网的 


\begin{abstract}
普及化更有所发展，到现在还是非常活跃。这个记忆主要是民间记忆，在各 阶段需要与一直有意控制历史和集体记忆的党国争取一个呼吸空间。有关 文革的议题特别难以取得官方的容忍。所以，知青记忆的全景图不但因过去 的经历和现在的状况与愿望不同而多元化, 还因各种政治顾虑而复杂化。本 文没有提供这个广大的记忆领域的全景图的奢望目标，只是通过不同的例 子来反思知青保存记忆的强大愿望的意义。文章强调只有在真正尊重历史 的情况下, 这代人才能超越不同记忆的冲突, 而找到自己命运中的意义。在 这方面, 一些知青已经有不可忽略的贡献。
\end{abstract}

关键词: 知青; 文化大革命; 集体记忆; 中国; 上山下乡运动

\title{
References
}

Barmé, Geremie. 1996. Shades of Mao: The Posthumous Cult of the Great Leader. Armonk, NY: M.E. Sharpe.

Barmé, Geremie. 2000. In the Red: On Contemporary Chinese Culture. New York: Columbia University Press.

Bernstein, Thomas P. 1977. Up to the Mountains and Down to the Villages: The Transfer of Youth from Urban to Rural China. New Haven, CT: Yale University Press.

Bonnin, Michel. 1986. "The social function of Chinese literature since 1979: the case of the 'lost generation'." In H. Martin (ed.), Cologne Workshop 1984 on Contemporary Chinese Literature. Cologne: Deutsche Welle, 233-238.

Bonnin, Michel. 1996. "Peking's theme restaurants: nostalgia for the bad old days." China Perspectives 4(March-April), 35-41.

Bonnin, Michel. 2004. Génération perdue. Le mouvement d'envoi des jeunes instruits à la campagne, Chine 1968-1980. Paris: Editions de l'Ecole des Hautes Etudes en Sciences Sociales.

Bonnin, Michel. 2006. "The 'lost generation': its definition and its role in today's Chinese elite politics.” Social Research - An International Quarterly of the Social Sciences 73(1), 245-274.

Bonnin, Michel. 2007. "The threatened history and collective memory of the Cultural Revolution's lost generation." China Perspectives 4, http://chinaperspectives.revues.org/2573. Accessed 4 July 2016.

Bonnin, Michel. 2010. "Shanghai et l'héritage douloureux du maoïsme: le destin de la 'génération perdue'." In Nicolas Idier (ed.), Shanghai: histoire, promenades, anthologie et dictionnaire. Paris: Robert Laffont, Bouquins, 931-972.

Bonnin, Michel. 2011. "Une génération oubliée? Mémoire, culture et entraide chez les anciens jeunes intruits. Monde Chinois 25, 106-112.

Bonnin, Michel. 2013. The Lost Generation - The Rustication of China's Educated Youth (19681980). Hong Kong: Chinese University of Hong Kong Press.

Chen, Fong-ching, and Jin Guantao. 1997. From Youthful Manuscripts to River Elegy: The Chinese Popular Cultural Movement and Political Transformation, 1979-1989. Hong Kong: The Chinese University of Hong Kong Press.

Chen, Yixin. 1999. "Cong xiafang dao xiagang: Zhongguo de zhiqing yidai, 1968-1998" (From sentdown to laid-off: China's sent-down generation, 1968-1998). Ershiyi shiji 8, 219-239.

Deng, Peng (ed.). 2015. Exiled Pilgrims: Memoirs of Pre-Cultural Revolution Zhiqing. Leiden: Brill.

Ding, Yizhuang. 1998. Zhongguo zhiqing shi. Chulan (1953-1968) (A History of the Chinese Educated Youth. The First Waves, 1953-1968). Beijing: Zhongguo shehui kexue chubanshe.

Fan, Chenggang, Su Tongliao, Mei Zhounan and Pan Mengqi. 2013. "'Women shi shaoshu': wenge chanhuizhe de nuli yu kundun" ("We are a minority": the efforts made and difficulties faced by the people who repent for what they did during the Cultural Revolution), Nanfang zhoumo, 20 July. 
Feng, Jicai. 1991. Yibaige ren de shi nian (How a Hundred People Spent Ten Years). Nanjing: Jiangsu wenyi chubanshe.

Guo, Daohui. 2010. "Siqian lao ganbu dui dangshi de yici minzhu pingyi” (A democratic evaluation of the Party history by 4,000 old cadres). Yanhuang chunqiu 4.

Hartog, François. 2003. Régimes d'historicité: présentisme et expériences du temps. Paris: Editions du Seuil.

Hubbert, Jennifer. 2005. "Revolution is a dinner party. Cultural Revolution restaurants in contemporary China." China Review 5(2), 125-150.

Hunxi hei tudi bianweihui. 1991. Hunxi hei tudi (Our Soul is Linked to the Black Earth). Suzhou: Jiangsu renmin chubanshe.

Jin, Guangyao, Jin Dalu and Shanghaishi zhishi qingnian lishi wenhua yanjiuhui (eds.). 2014. Zhongguo xin fangzhi zhishi qingnian shangshan xiaxiang shiliao jilu, qi juan ( $A$ Compilation of Historical Materials from the New Annals of China on the Rusticated Youth, 7 vols.). Shanghai: Shanghai shudian chubanshe and Shanghai renmin chubanshe.

Kong, Huiyun (ed.). 1998. Zhiqing shenghuo huiyi (Remembrances of Zhiqing Life). Jinan: Shandong huabao chubanshe.

Lam, Willy Wo-lap. 1995. China after Deng Xiaoping: The Power Struggle in Beijing since Tiananmen. Hong Kong: PA Professional Consultants.

Lao, Gui. 2009. Liehuo zhong de qingchun (A Youth Spent in the Midst of Fierce Fire). Beijing: Zhongguo shehui kexue chubanshe.

Le Goff, Jacques. 1988. Histoire et mémoire. Paris: Gallimard, Folio Histoire.

Lin, Shengbao, and Jin Dalu. 2014. Shanghai zhishi qingnian shangshan xiaxiang yundong jishilu, 1968-1981 (A Chronicle of the Shanghai Rustication Movement, 1968-1981). Shanghai: Shudian chubanshe.

Liu, Xiaomeng. 1998. Zhongguo zhiqing shi. Dachao (1968-1980) (A History of the Chinese Educated Youth. The Big Upsurge, 1968-1980). Beijing: Zhongguo shehui kexue chubanshe.

Liu, Xiaomeng. 2004. Zhongguo zhiqing koushushi (Oral History of the Chinese Educated Youth). Beijing: Zhongguo shehui kexue chubanshe.

Michel, Jean-Jacques, and Huang He. 1978. Avoir 20 ans en Chine ... à la campagne (To Be Twenty in China's Countryside). Paris: Editions du Seuil.

Naughton, Barry. 2011. "The impact of the Tiananmen crisis on China's economic transition." In Jean-Philippe Béja (ed.), The Impact of China's 1989 Tiananmen Massacre. New York: Routledge, 154-178.

Ownby, David. 2010. Falungong and the Future of China. New York: Oxford University Press.

Palmer, David. 2007. Qigong Fever: Body, Science and Utopia in China. New York: Columbia University Press.

Pan, Mingxiao (Michel Bonnin). 2009 and 2010. Shiluo de yidai: Zhongguo de shangshan xiaxiang yundong, 1968-1980 (The Lost Generation: The Chinese Rustication Movement, 1968-1980). Hong Kong: Chinese University Press. (A slightly different version of this book has been published in 2010 by Zhongguo dabaike quanshu chubanshe, Beijing).

Pedroletti, Brice. 2014. "China's former Red Guards turn their backs on Maoism," The Guardian Weekly, 4 May.

Qin, Liyan. 2006. "The sublime and the profane: a comparative analysis of two fictional narratives about sent-down youth." In Joseph Escherick, Paul Pickowicz and Andrew G. Walder (eds.), The Chinese Cultural Revolution as History. Stanford, CA: Stanford University Press, 240-266.

"Qingchun Wuhui” bianjizu. 1991. "Qingchun Wuhui-Yunnan zhibian shenghuo jishi (No Regret for our Youth - Chronicles of the Life of Educated Youth Supporting the Border Region in Yunnan). Chengdu: Sichuan wenyi chubanshe.

$\mathrm{Qu}, \mathrm{Bo}$, and Luo Xiaowen (eds.). 2006. Jufeng guaguo yaredai yulin (A Hurricane Passed over the Subtropical Forest). Beijing: Zhongguo guoji shiyejia.

Ruan, Ming. 1994. Deng Xiaoping: Chronicle of an Empire. Boulder, CO: Westview Press. 
Walder, Andrew G. 2015. China under Mao: A Revolution Derailed. Cambridge, MA: Harvard University Press.

Wang, Lijian. 2008. Huimou qingchun: Zhongguo zhiqing wenxue (Looking Back on Youth: The Zhiqing Literature). Taipei: Airiti Press.

Wang, Runsheng. 1992. "Deuxième vague de 'pénétration du savoir occidental' et métamorphose idéologique en Chine." Perspectives Chinoises 7, 37-41.

Wang, Xiaobo. 1997. Huangjin shidai (The Golden Age). Chongqing: Chongqing chubanshe.

Xi, Jinping. 2002. "Wo shi huangtudi de erzi" (I am a son of the yellow earth). Quanguo xin shumu 12, http://mall.cnki.net/magazine/Article/QGXS200212029.htm. Accessed 1 August 2016.

Xiao, Han. 2014. "Confessions of the Cultural Revolution," The New York Times, 27 January.

Xin, Ziling. 2007. Hong taiyang de yunluo (The Fall of the Red Sun). Hong Kong: Shuzuofang.

Xu, Naijian. 1981. Yangbai de wuran (The Pollution of Yangbai). In Li Guowen, Gao Xiaosheng, et al., Pan - duanpian xiaoshuoji (Aspirations: A Collection of Short Stories). Chengdu: Sichuan renmin chubanshe, 74-85.

Xu, Youyu. 1998. 1966: Women na yidai de huiyi (1966: Memories of Our Generation). Beijing: Zhongguo wenlian chuban gongsi.

$\mathrm{Xu}$, Youyu. 1999a. Xingxing sese de zaofan: hongweibing jingshen suzhi de xingcheng ji yanbian (Rebels of All Stripes: A Study of Red Guard Mentalities). Hong Kong: Chinese University Press. Xu, Youyu. 1999b. Moran huishou (Turning My Head Back Suddenly). Henan: Renmin chubanshe.

Yang, Guobin. 2003. "China's zhiqing generation: nostalgia, identity and cultural resistance in the 1990s." Modern China 29(3), 267-296.

Yang, Jian. 2002. Zhongguo zhiqing wenxue shi (A History of the Literature of the Chinese Educated Youth). Beijing: Zhongguo gongren chubanshe.

Ye, Xin. 1980. "Cuotuo suiyue" (The wasted years). Shouhuo 5, 4-80; 6, 156-254.

Zhang, Liang, Andrew J. Nathan and Perry Link. 2002. The Tiananmen Papers. New York: Public Affairs.

Zhang, Xinxin, and Sang Ye. 1986. Beijingren (People of Beijing). Shanghai: Wenyi chubanshe. 